\title{
Landslide Vulnerability Analysis Due to Earthquake Based on Seismic Vulnerability and Slope of the Slip Surface in Tritis, Yogyakarta
}

\author{
F. Edwin Wiranata \\ Basic Engineering Laboratory, Faculty of Industrial Technology, Universitas Atma Jaya Yogyakarta \\ Jalan Babarsari No 43, Yogyakarta 55281
}

\begin{abstract}
Tritis is a hamlet in Kulon Progo Regency, located in an area with steep slope topography making it vulnerable to landslides. Ground movement vulnerability due to earthquakes is controlled by several factors, one of which is the seismic vulnerability index whose value can be obtained through microtremor measurements by $\mathrm{H} / \mathrm{V}$ analysis. In addition, the dynamic trigger factor for landslides is the slope. The slope of the surface is not always the same as the slope of the slip surface because it is observed from the surface, while the slip surface is under the soil layer and requires measurements using the geophysical method to determine the surface model. For this reason, an analysis is needed to compare the landslide vulnerability between these two factors, the slope of the surface and the slope of the slip surface. From the measurement results, there is a significant difference between the slope and the slope of the slip surface at the same site in the north of the slope by $15.17^{\circ}$ with a seismic vulnerability index $(\mathrm{kg})$ of 2.5 . The distribution of seismic vulnerability index in all slopes ranges from 0.075 to 7.33 , dominated by areas with slopes $>18^{\circ}$. High landslide vulnerability is in the southern and northern areas.

Keywords: landslide; slip surface; H/V; vulnerability.

*Corresponding author: edwin.wiranata@uajy.ac.id
\end{abstract}

Article history: Received 11 June 2020, Accepted 29 September 2020, Published January 2021. http://dx.doi.org/10.12962/j24604682.v17i1.6988

2460-4682 (C)Departemen Fisika, FSAD-ITS

\section{INTRODUCTION}

Landslides occur due to the instability of the soil on the slopes, resulting in a process of attaining an equilibrium state towards a new, relatively more stable state. The process of achieving an equilibrium state can occur due to a disturbance in the slope balance, resulting in an imbalance condition [1]. Disruption to slope balance can occur due to a combination of several natural factors, such as slope, rock and soil conditions, groundwater conditions on the slopes, and other triggering factors, such as high rainfall, material taking, construction of roads/buildings that cut slopes, and earthquake [2]. Massive ground movement due to earthquakes in an area occurs when the shear strain is $1000 \times 10^{-6}$ and experiences landslides and liquefaction if the shear strain is greater than or equal to $10,000 \times 10^{-6}$ [3]. The value of the shear strain is controlled by the seismic vulnerability index $(\mathrm{Kg})$, which is mathematically related to amplification and the natural frequency in the area.

The amplification factor in the soil is the response of the surface layer to an earthquake which reflects the amplification of the wave as it passes through the lower impedance layer boundary. The amplification factor illustrates the amplification of the accelerated ground motion from the bedrock to the surface. This increase is due to the impedance contrast be- tween the bedrock and surface layer [4].

The slope of the surface is a dynamic triggering factor for landslides, a trigger that causes changes in the resultant force due to changes in dynamic factors. The greater the slope angle, the higher the potential for landslides to occur [5]. In many landslide studies, the surface slope is a parameter to determine the level of landslide vulnerability in an area [6]. Meanwhile, the landslide event maintains contact between the moving soil mass and the layer below it [7]. This means that the soil mass moves over a surface, which is called the slip surface, which is the plane that lies between the moving soil mass and the hard rock below it. The implication is that the landslide vulnerability which is determined by the surface slope and the slope of the slip surface can obtain different values.

Tritis Hamlet is located in Ngargosari Village, Samigaluh District, Kulon Progo Regency. This area has many areas with a sloping appearance. Also, this area is used as a tourist destination, so there needs to be a study of landslide vulnerability around this area. The study of determining the landslide vulnerability due to the earthquake was carried out on a slope in Tritis Village, by comparing the level of vulnerability resulting from the surface slope parameter and the slip surface slope parameter. 


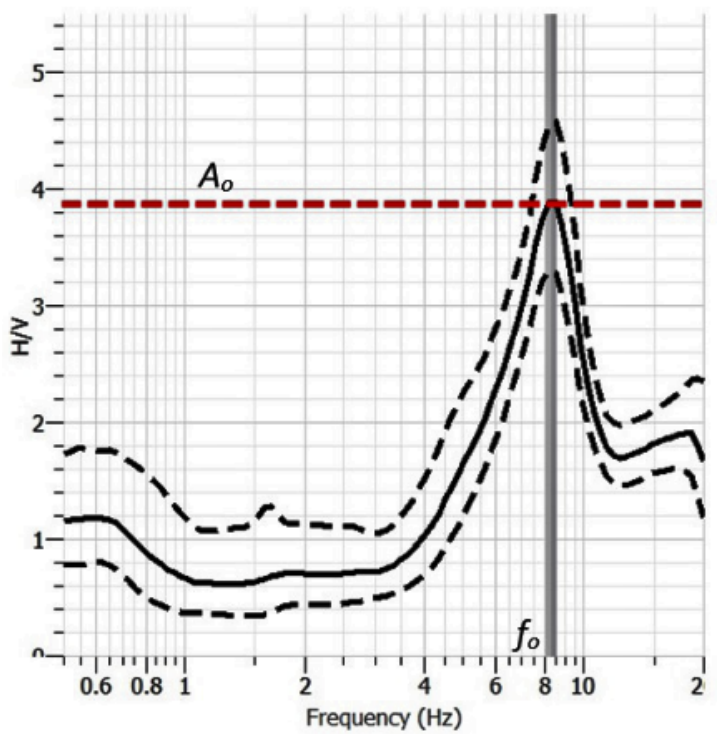

FIG. 1: H/V curve of 1 site in the southern area.

\section{METHOD}

The slope area is located on the border between Yogyakarta and Central Java Provinces. The location is within the coordinates of $110^{\circ} 08^{\prime} 52.0^{\prime \prime} \mathrm{E}$ to $110^{\circ} 08^{\prime} 53.55^{\prime \prime} \mathrm{E}$ and $7^{\circ} 38^{\prime} 57.11^{\prime \prime} \mathrm{S}$ to $7^{\circ} 38^{\prime} 52.55^{\prime \prime} \mathrm{S}$. At this location, the determination of the seismic vulnerability index and the depth of the slip surface was carried out by HVSR (Horizontal to Vertical Spectral Ratio) analysis and using the data of the soil thickness from the author's research results in the thesis which can be accessed through the UGM repository [8]. From the results of the HVSR analysis, amplification values and natural frequencies can be obtained, then the seismic vulnerability index value can be calculated using the following equation [9]:

$$
K_{g}=\frac{A^{2}}{f_{\circ}^{2}}
$$

where $A$ is amplification, and $\mathrm{f}_{\circ}$ is the natural frequency $(\mathrm{Hz})$. The seismic vulnerability index $(\mathrm{Kg})$ is an index that describes the level of vulnerability to the deformation of a soil layer on the surface due to earthquakes which can cause soil movement on slopes. Meanwhile, to obtain the accurate slope, altitude measurements were made using 2 Trimble GPS, with one receiver measuring the height at the base and the other receiver recording the data at the receiver rover.

The determination of landslide vulnerability was analyzed using the Simple Additive Weight (SAW) method. This method involves several criteria that are used to analyze a decision in determining priority, evaluation, and selecting attributes that consist of several alternatives [10]. In this process, normalization of the input matrix is required so that it can be compared with all the alternative ratings. Because the seismic vulnerability index and the slope parameter are the trigger factors, meaning that the higher the value, the higher the landslide vulnerability level, so that the normalization for-

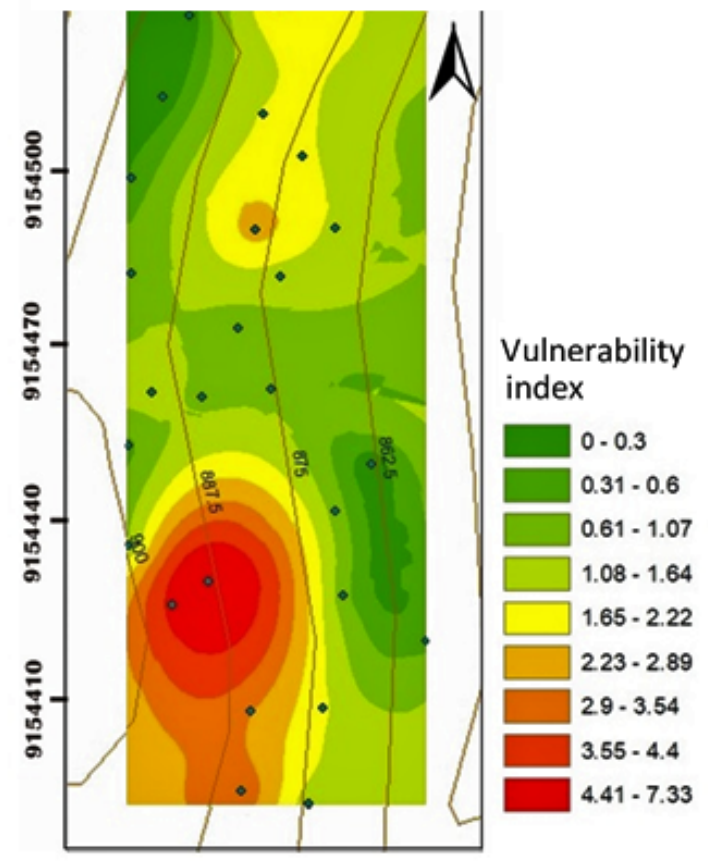

FIG. 2: The map of vulnerability index.

mulation can be calculated using the following equation:

$$
r_{i j}=\frac{x_{i j}}{\max _{i} x_{i j}}
$$

where $\mathbf{r}_{i j}$ is normalization, $\mathbf{x}_{i j}$ is the row and column of the matrix, and maxi is the maximum value of each row and column.

In this study, the seismic vulnerability index and the slope parameter have the same weight. Thus, the landslide vulnerability level with these two criteria can be calculated using the following equation:

$$
V_{i}=\Sigma_{j=1}^{n} w_{j} r_{i j}
$$

where $\mathrm{V}_{i}$ is the final alternative value which is the landslide vulnerability level and $\mathrm{w}_{j}$ is the criterion weight.

\section{RESULT AND DISCUSSION}

The natural frequency and maximum amplification at a point are obtained through $\mathrm{H} / \mathrm{V}$ analysis on microtremor data. From this analysis, the H/V curve in Fig. 1 shows the value of natural frequency (frequency at high $\mathrm{H} / \mathrm{V}$ amplitude) and amplification (highest amplitude on the H/V curve). By modeling the HVSR curve with thickness variation input, it is known that thickness variations only have a significant effect on natural frequencies, whereas with the input of the shear wave velocity variations affect natural frequencies and amplification [11]. This shows that the natural frequency and the amplification are not significantly correlated. 

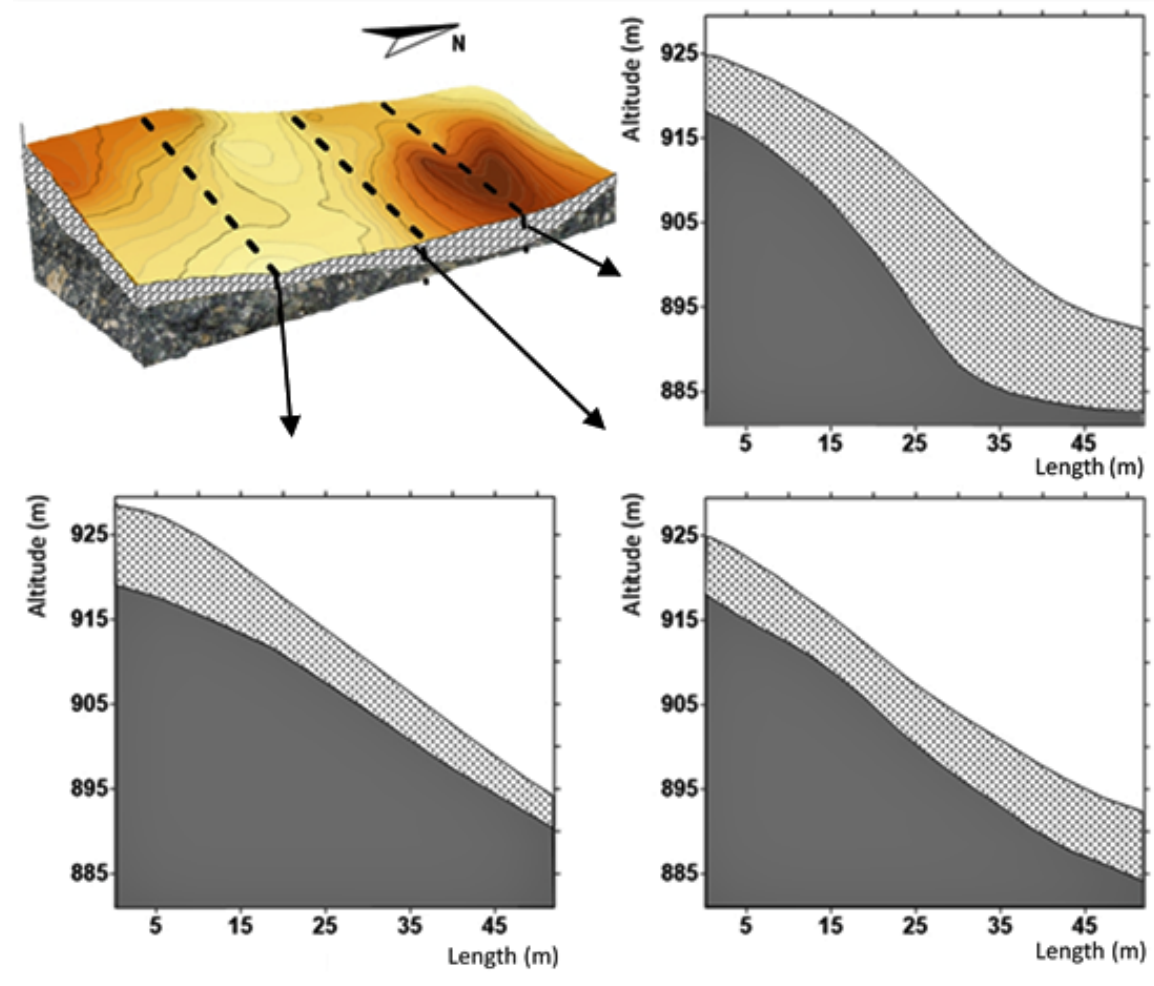

FIG. 3: The surface slope and slip surface profile.

Because amplification and frequency are not correlated significantly, in the assessment, the local effect hazard uses a soil vulnerability index which can be calculated by Eq.(1). The estimation results of this vulnerability index as in Fig. 2 show that the distribution of the seismic vulnerability index ranges from 0.075-7.33 with the index high vulnerability spreads in the south, while the low vulnerability index relatively spreads to the north. The southern area becomes a weak zone to experience ground movement due to earthquakes. There are 3 points in the south with a vulnerability index $>3,4$, where this magnitude indicates that in this area, the soil layer is susceptible to deformation in the form of cracks due to earthquakes [12].

From the data of soil slope obtained through measurements with GPS and the data of soil thickness on the Tritis slope, a 3D model of the slope was created which can be seen in Fig. 3. In general, the slope is dominated by areas with a slope greater than 180 , with varying slope distribution. Landslides occur when there is a displacement of soil mass caused by gravity. On slopes, the magnitude of the gravitational force on the soil mass is affected by the slope as a dynamic trigger [13]. Meanwhile, rainfall, soil thickness, land use, rock weathering, bed structure, and soil texture are the trigger factors. This makes the slope of the surface factor has a great weight in many landslide vulnerabilities analyzes. By looking at the surface structure of the slip surface on the Tritis slope, in general, the shape of the soil layer above it follows the geometry of the slip surface below it. However, in the northern area where the soil layer is relatively thick, the geometry of the slip surface is slightly steep compared to the shape of the overlying subsoil.

The northern area is the focus of this study because of the difference in structure and slope between the soil layer and the slip surface underneath as shown in the upper right of Fig. 3. The slope of this area reaches $42.50^{\circ}$ with the large layer thickness. Meanwhile, the slope of the slip surface in the same zone reaches $57.67^{\circ}$, so there is a quite large difference, which is $15.17^{\circ}$ relative to the measured slope above it. Whereas in the central and southern regions, the geometry of the slip surface relatively follows the geometry of the surface slope, with an average slope of $26.80^{\circ}$ with a difference of $1^{\circ}-5^{\circ}$ in the central area of the slope, and an average slope of $18.90^{\circ}$ with a difference of $1^{\circ}-3^{\circ}$ in the southern area. These results are calculated based on the slope difference between the surface slope and the slip surface slope below it.

The slope difference between the structure of the slip surface and the surface slopes will affect the levels of landslide vulnerability when the vulnerability mapping is carried out. A mass slipping over an inclined plane should be affected by the slope of the plane, and not affected by the slope of the mass itself. The use of surface slope parameters as the cause of landslides usually assumes that the geometry of the slip surface is congruent with the geometry of the surface slope so that the slopes of both are assumed to be the same. However, in reality, the geometries of the two slopes are not always congruent, so the use of surface slope parameters as the cause of landslides is not correct for the slopes in Tritis.

Fig. 4 shows two landslide vulnerability maps using the 


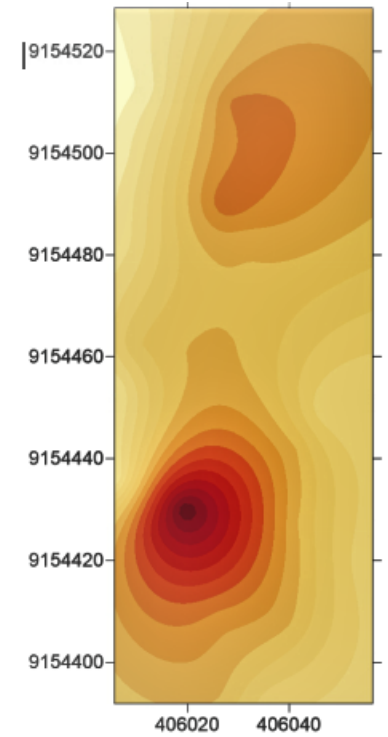

(a)

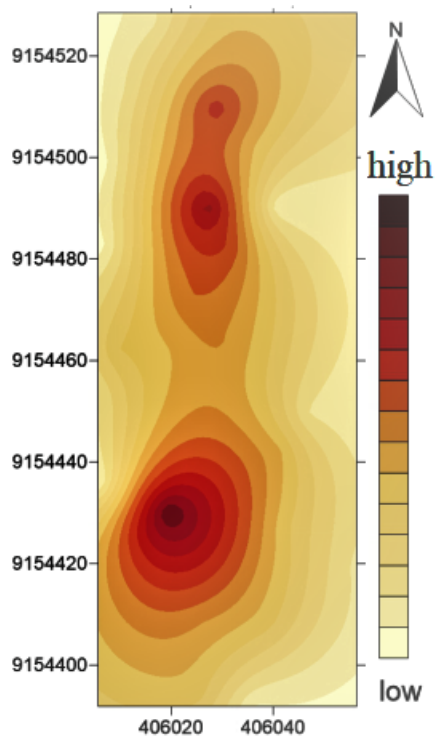

(b)
FIG. 4: H/V curve of 1 site in the southern area.

SAW method, based on two different vulnerability parameters, the surface slope factor, and the slip surface slope factor. Based on the two vulnerability maps in Fig. 4, the areas with high vulnerability are in the south of the slope, while from Fig. 4(b), the areas with high vulnerability are in the north and south of the slopes. In the south of the slope, both Fig. 4(a) and Figure 4.b show the similarity because the surface slope and the slip surface are not much different so that the vulnerability in this area is thought to be controlled only by the high seismic vulnerability index. In the northern slope area, Fig. 4(b) shows high landslide vulnerability while Fig.4(a) shows a medium level. This difference in vulnerability is affected by the difference in slope and slip surface, which is quite large, reaching $15.17^{\circ}$ so that it seems like a potential disaster that cannot be seen on the surface. Moreover, the slopes are dominated by clay and in the northern area, the layers are quite thick, which means that the high accumulation of water when it rains will create a slip plane zone which increases the potential for landslides in this area [14]. However, soil conditions in the northern area are assumed to vary because not all areas in the north have a high seismic vulnerability index.

A seismic vulnerability index that is not quite high in the north area indicates the solid and compact soil conditions. However, Fig. 2 shows an increasing trend of vulnerability in the UTM coordinates at 9154490 of north-south and at 406027 of west-east reaching 2.5 , where this point is an area with high soil thickness and high slope differences in surface slope and slip surface slope.

\section{CONCLUSION}

Earthquake-prone zones are located on the north and south areas of the slope. In the south, the high vulnerability is controlled by a high seismic vulnerability index, while in the north, the high vulnerability is controlled by two parameters, the seismic vulnerability index and the slip surface slope. In the north of the slope, the slope difference in angle between the surface slope and the slip surface is quite high, so that the potential for ground motion seems low when viewed from the surface with the surface slope parameter as a vulnerability parameter, even though the potential for ground motion in this area is quite high because of the steep slope of the slip surface below the soil layer.

\section{Acknowledgments}

Thank you to Urip N. Prabowo, as the provider of research funding and the Geophysics Laboratory of Gadjah Mada University, Yogyakarta, as the provider of measurement equipment. Thanks also to all parties and institutions who have helped carry out this research.
[1] Z. Zakaria, "Model Starlet, Suatu Usulan untuk Mitigasi Bencana Longsor dengan Pendekatan Genetika Wilayah (Studi Kasus: Longsoran Citatah, Padalarang, Jawa)”, Jurnal Geologi Indonesia, vol. 5, no. 2, pp. 93-112, 2010.

[2] R. Hartini et al., "Kerawanan Longsor Lereng Jalan Studi Kasus Ruas Jalan Sukasada-Candi Kuning", Jurnal Spektran, vol. 2, no. 2, pp. 10-15, 2014.

[3] K. Ishihara, "Evaluation of Soil Properties for Use in Earthquake Response Analysis", Proc. Int. Symp. on Numerical Model in Geomech, 1982.

[4] W. Partono et al., "Aplikasi Metode HVSR pada Perhitungan Faktor Amplifikasi Tanah di Kota Semarang", Media Komunikasi Teknik Sipil, pp. 125134, 2013.

[5] A.S. Muntohar, "Pengaruh Rembesan Air dan Kemiringan Lereng Terhadap Keruntuhan Lereng”, Jurnal Teknik Sipil, vol.
1, no. 2, pp. 162, 2006

[6] W.A. Gemilang et al., "Kerentanan Pesisir Terhadap Bencana Tanah Longsor Di Bungus, Sumatera Barat Dan Sekitarnya Menggunakan Metode Storie", Jurnal Geosaintek, vol. 3, no. 1, pp. 37-41, 2007.

[7] A. Kazeev, and G. Postoev, "Landslide investigations in Russia and the former USSR", Natural Hazard, vol. 88, pp. 81-100, 2016.

[8] F.E. Wiranata, "Identifikasi Bidang Gelincir dan Area Rawan Longsor pada Lereng Berdasarkan Pengukuran Mikrotremor di Dusun Tritis Kecamatan Samigaluh Kulon Progo”, Thesis, Universitas Gadjah Mada, Yogyakarta, Indonesia, 2016.

[9] Y. Nakamura, "Clear Identification of Fundamental Idea of Nakamura's Technique and its Applications", in Proc XII World Conf, New Zeeland, 2000, Earthquake Engineering. 
[10] F.S. Azar, "Multiattribute Decision-Making: Use of Three Scoring Methods to Compare the Performance of Imagining techniques for Breast Cancer Detection”, J Technical Reports (CIS), vol. 119, 2000.

[11] Sungkono, and B.J. Santosa, "Karakteristik Kurva Horizontalto-Vertical Spectral Ratio: Kajian Literatur dan Pemodelan", Jurnal Neutrino, vol 4, no. 1, pp. 1-15, 2011.

[12] U.N. Prabowo et al., "Local site effect of soil slope based on microtremor measurement in Samigaluh, Kulon Progo Yogyakarta", in IOP Conf. Series: Journal of Physics, Conf. Se- ries: 997 (2018) 012007, 2017.

[13] K. Priyono Dwi, and Priyono, "Analisis Morfometri dan Morfostruktur Lereng Kejadian Longsor di Kecamatan Banjarmangu Kab Banjarnegara", Forum Geografi, vol. 22, no. 2, pp. 72-84, 2008.

[14] I. Permanajati et al., "Identifikasi Bidang Gelincir dengan Pendekatan Model Tingkat Pelapukan pada Lokasi Longsoran Purwoharjo, DIY", in The 36th HAGI and 40th IAGI Annual Convention and Exhibition, Makassar, 2011. 